\title{
University of Florida Potato Variety Trials Spotlight: 'Fabula'1
}

\author{
Mario H. M. L. Andrade, Rodrick Z. Mwatuwa, Christian T. Christensen, Pam Solano, and \\ Lincoln Zotarelli²
}

\section{Introduction}

There are several potato varieties available in the market today. Most of them have been bred or developed in production regions other than Florida. The University of Florida Potato Variety Evaluation Program screens new germplasm from public and private breeding programs and identifies the most promising cultivars for commercial potential considering broad adaptability to Florida climate and conditions and market purpose: processing, freshmarket and specialty-type varieties. Over the years, the UF/ IFAS Potato Variety Program has become an important reference to vegetable growers, seed producers, processors, crop insurance agencies, and brokers looking for alternative potato varieties to explore different markets, improved characteristics, and yield. This UF/Potato Variety Trials Spotlight presents a summary of the field evaluation of tuber yield and quality performance of the potato variety 'Fabula' cultivated in Florida.

\section{General Comments}

'Fabula' is a potato variety that is commonly grown for the fresh potato market. The variety was selected from progeny of a cross between 'Monalisa' and 'Hudson'. It was released in 2005 by D. Biedmond B.V. of the HZPC in the Netherlands. 'Fabula' demonstrates good tuber characteristics and high yield superior to its commercial standard, 'LaChipper'. Tuber production and quality results provided in this spotlight are summarized from various trials conducted by the UF/IFAS Hastings Agricultural Extension Center from 2001 to 2016, excluding 2009.

\section{General Characteristics}

'Fabula' tubers have a buff skin color with a slightly netted texture and creamy flesh color (Figure 1). According to Florida rating codes for potato tuber characteristics (Table 1), the tubers have a fair/good appearance with mostly oblong shape and eyes that are unevenly distributed with intermediate/shallow depth (Table 3). The variety has medium to long dormancy (time required for sprout emergence). This variety has high yield potential under Florida production conditions (Tables 2 and 3). On average, marketable yield is $265 \mathrm{cwt} /$ acre, approximately $11 \%$ greater than the commercial standard 'LaChipper', with $91 \%$ of the tubers found between A1 and A3 tuber size classifications.

1. This document is HS1294, one of a series of the Horticultural Sciences Department, UF/IFAS Extension. Original publication date May 2017. Revised February 2021. Visit the EDIS website at https://edis.ifas.ufl.edu.

2. Mario H. M. L. Andrade, research scholar; Rodrick Z. Mwatuwa, research assistant; Christian T. Christensen, regional specialized agent II, director, UF/IFAS Hastings Agricultural Extension Center; Pam Solano, biological scientist; and Lincoln Zotarelli, associate professor; Horticultural Sciences Department, UF/IFAS Extension, Gainesville, FL 32611.

The Institute of Food and Agricultural Sciences (IFAS) is an Equal Opportunity Institution authorized to provide research, educational information and other services

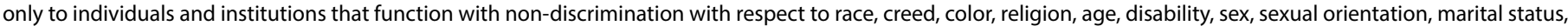

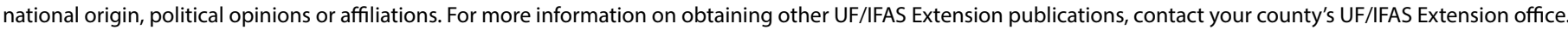
U.S. Department of Agriculture, UF/IFAS Extension Service, University of Florida, IFAS, Florida A \& M University Cooperative Extension Program, and Boards of County Commissioners Cooperating. Nick T. Place, dean for UF/IFAS Extension. 


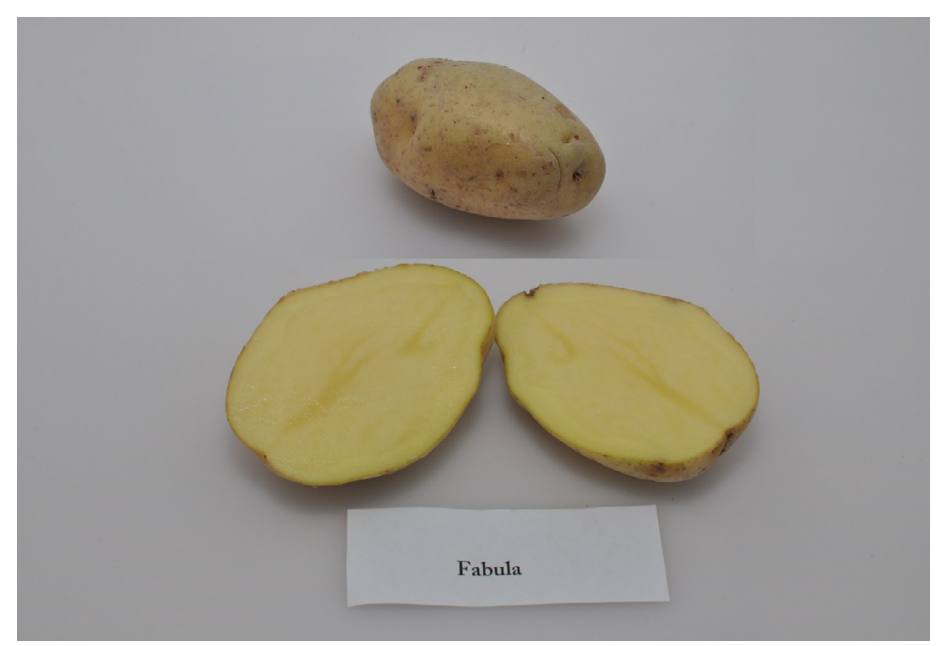

Figure 1. Typical tuber and internal fresh color of 'Fabula' potato variety.

Credits: Lincoln Zotarelli, UF/IFAS

\section{Diseases}

On average, 'Fabula' demonstrates no incidence of hollow heart, brown rot, corky ringspot, or internal heat necrosis under Florida conditions (Table 3). It is immune to potato wart (Synchytrium endobioticum [race 1]), resistant to golden nematode (Globodera rostochiensis), and exhibits moderate resistance to leaf roll virus, potato virus $\mathrm{Y}$, common scab (Streptomyces scabies), and tuber late blight (Phytophthora infestans). It is moderately susceptible to potato virus $\mathrm{X}$ and foliage late blight. The standard UF/ IFAS Extension recommended disease and weed control program described under Potato Production (Chapter 14 of the Vegetable Production Handbook for Florida, http://edis. ifas.ufl.edu/cv131) should be followed.

\section{Season Length and Growth}

'Fabula' is a medium-to-late-maturing variety. Under Florida conditions, the season length is 95 days on average from planting to harvesting. This depends on weather conditions during the growing season. The plants should be harvested two weeks after vine kill to improve tuber maturation and skin set. Potatoes with proper skin set maintain better skin color, lose less weight in storage, and are more resistant to bruising and soft rot. For more information about vine killing on potatoes, see Potato Vine Killing or Desiccation (Zotarelli et al. 2016). Late in the season, tuber size should be checked regularly to harvest tubers with desirable marketable size. Soil moisture should be managed late in the season to avoid high soil moisture conditions that cause enlarged lenticels and delayed skin set.

\section{Fertilization}

UF/IFAS trial plots are normally fertilized with 200 to 230 $\mathrm{lb} / \mathrm{ac}$ of $\mathrm{N}$. The first application of $100 \mathrm{lb} / \mathrm{ac}$ of $\mathrm{N}$ (granular) is typically incorporated in the bed prior to planting, followed by one or two side-dress fertilizer applications at emergence and/or at tuber initiation. Phosphorus and potassium applications follow the UF/IFAS guidelines described in Liu et al. (2020) and normally range between 45 to $100 \mathrm{lb} / \mathrm{ac}$ of $\mathrm{P}_{2} \mathrm{O}_{5}$ and 170 to $235 \mathrm{lb} / \mathrm{ac}$ of $\mathrm{K}_{2} \mathrm{O}$.

\section{Planting}

A seed piece of 2.5 to $3 \mathrm{oz}$ is recommended for planting. This variety should be planted with 40 inches between rows and 8 inches between plants, at 3 to 4 inches deep. A seed rate of 2,000 to $3,000 \mathrm{lb} /$ acre of seed is expected.

\section{Other Information}

For additional information on cultivation and weed and disease management, see the Potato Production chapter of the Vegetable Production Handbook, available at https://edis. ifas.ufl.edu/cv131.

\section{References}

Canadian Food Inspection Agency. n.d. "Fabula." https:// www.inspection.gc.ca/DAM/DAM-plants-vegetaux/STAGING/text-texte/pota_vari_fabula_1312587515433_fra.pdf. Accessed April 11, 2020.

Hutchinson, C. M., J. M. White, D. M. Gergela, P. A. Solano, K. G. Haynes, R. Wenrich, and C. S. Lippi. 2003. "Performance of chip processing potato varieties in northeastern Florida." HortTechnology 13 (4): 706-711.

Liu, G., E. H. Simonne, K. T. Morgan, G. J. Hochmuth, S. Agehara, and R. Mylavarapu. 2020. Chapter 2. Fertilizer Management for Vegetable Production in Florida. Vegetable Production Handbook for Florida, 2020-2021 Edition. CV296. Gainesville: University of Florida Institute of Food and Agricultural Sciences. http://edis.ifas.ufl.edu/cv296

Sisson, J. A., and G. A. Porter. 2002. "Performance evaluations of potato clones and varieties in the northeastern states-1999." Maine Agr. For. Expt. Sta., Misc. Publ. 751.

Zotarelli, L., J. P. Dittmar, P. D. Roberts, J. Desaeger, and B. Wells. 2020. Chapter 14. Potato Production. Vegetable Production Handbook for Florida, 2020-2021 Edition. HS733. Gainesville: University of Florida Institute of Food and Agricultural Sciences. http://edis.ifas.ufl.edu/cv131 
Zotarelli, L., S. Sargent, P. Dittmar, and M. Makani. 2016.

Potato Vine Killing or Desiccation. HS181. Gainesville:

University of Florida Institute of Food and Agricultural

Sciences. http://edis.ifas.ufl.edu/hs181

Table 1. Florida's rating codes for potato vine maturity and tuber characteristics.

\begin{tabular}{|c|c|c|c|c|c|c|c|}
\hline \multicolumn{8}{|c|}{ Tuber Characteristics $^{1}$} \\
\hline $\begin{array}{c}\text { Rating } \\
\text { Code }\end{array}$ & Vine Maturity & $\begin{array}{c}\text { Internal Flesh } \\
\text { Color }\end{array}$ & Skin Color & Skin Texture & Tuber Shape & Eye Depth & $\begin{array}{c}\text { Overall Tuber } \\
\text { Appearance }\end{array}$ \\
\hline 1 & dead & white & purple & partial russet & round & very deep & very poor \\
\hline 2 & +- & cream & red & heavy russet & mostly round & -- & -- \\
\hline 3 & $\begin{array}{l}\text { yellow and } \\
\text { dying }\end{array}$ & light yellow & pink & $\begin{array}{l}\text { moderate } \\
\text { russet }\end{array}$ & round to oblong & deep & poor \\
\hline 4 & +- & medium yellow & dark brown & light russet & mostly oblong & -- & -- \\
\hline 5 & $\begin{array}{l}\text { moderatly } \\
\text { senesced }\end{array}$ & dark yellow & brown & netted & oblong & intermediate & fair \\
\hline 6 & +- & pink & $\tan$ & slightly netted & oblong to long & -- & -- \\
\hline 7 & $\begin{array}{l}\text { starting to } \\
\text { senesce }\end{array}$ & red & buff & moderately & mostly long & shallow & good \\
\hline 8 & +- & blue & white & smooth & long & -- & -- \\
\hline 9 & $\begin{array}{l}\text { green and } \\
\text { vigorous }\end{array}$ & purple & cream & very smooth & cylindrical & very shallow & excellent \\
\hline
\end{tabular}

Table 2. Summary of production statistics and specific gravity of 'Fabula' potato variety grown at the UF/IFAS Hastings Agricultural Extension Center, Hastings, FL from 2001 to 2016, excluding 2009.

\begin{tabular}{|c|c|c|c|c|c|c|c|c|c|c|c|c|c|}
\hline \multirow[t]{2}{*}{ Year } & \multirow{2}{*}{$\begin{array}{l}\text { Total } \\
\text { Yield }\end{array}$} & \multirow{2}{*}{$\begin{array}{c}\text { Marketable } \\
\text { Yield }^{1}\end{array}$} & \multirow{2}{*}{$\begin{array}{l}\% \text { of } \\
\text { STD }\end{array}$} & \multirow[t]{2}{*}{ Standard } & \multicolumn{6}{|c|}{ Size Class (Distribution by Class \%) ${ }^{2}$} & \multicolumn{2}{|c|}{ Range \% } & \multirow{2}{*}{$\begin{array}{l}\text { Specific } \\
\text { Gravity }\end{array}$} \\
\hline & & & & & C & B & A1 & A2 & A3 & A4 & $\begin{array}{l}\text { A1 to } \\
\text { A3 }\end{array}$ & Culls & \\
\hline 2001 & 242 & 219 & 72 & LaChipper & 0 & 3 & 31 & 44 & 23 & 0 & 97 & 6 & 1.053 \\
\hline 2002 & 311 & 245 & 108 & LaChipper & 0 & 2 & 36 & 47 & 15 & 0 & 98 & 19 & 1.059 \\
\hline 2003 & 486 & 417 & 132 & LaChipper & 2 & 3 & 32 & 37 & 27 & 0 & 96 & 11 & 1.056 \\
\hline 2004 & 529 & 472 & 223 & LaChipper & 3 & 3 & 50 & 38 & 6 & 0 & 94 & 5 & 1.063 \\
\hline 2005 & 361 & 323 & 129 & LaChipper & 1 & 5 & 59 & 31 & 4 & 0 & 94 & 5 & 1.054 \\
\hline 2006 & 324 & 269 & 88 & LaChipper & 0 & 7 & 77 & 15 & 0 & 0 & 92 & 10 & 1.053 \\
\hline 2007 & 408 & 381 & 128 & LaChipper & 0 & 6 & 70 & 22 & 2 & 0 & 94 & 1 & 1.052 \\
\hline 2008 & 339 & 286 & 150 & LaChipper & 1 & 11 & 73 & 15 & 1 & 0 & 88 & 4 & 1.060 \\
\hline 2010 & 244 & 153 & 82 & LaChipper & 2 & 14 & 83 & 1 & 0 & 0 & 84 & 25 & 1.047 \\
\hline 2011 & 373 & 314 & 111 & LaChipper & 1 & 7 & 53 & 29 & 10 & 0 & 92 & 8 & 1.050 \\
\hline 2012 & 216 & 149 & 61 & LaChipper & 2 & 9 & 53 & 24 & 12 & 0 & 89 & 27 & 1.044 \\
\hline 2013 & 136 & 106 & 85 & LaChipper & 2 & 9 & 77 & 11 & 0 & 0 & 89 & 13 & 1.044 \\
\hline 2014 & 324 & 183 & 126 & LaChipper & 3 & 18 & 71 & 7 & 1 & 0 & 79 & 30 & 1.053 \\
\hline 2015 & 235 & 197 & 59 & LaChipper & 3 & 8 & 59 & 30 & 0 & 0 & 89 & 6 & 1.039 \\
\hline 2016 & 165 & 128 & 108 & LaChipper & 2 & 10 & 65 & 12 & 11 & 0 & 88 & 11 & 1.048 \\
\hline Average & 313 & 256 & 111 & LaChipper & 1 & 8 & 59 & 24 & 7 & 0 & 91 & 12 & 1.052 \\
\hline
\end{tabular}

${ }^{1}$ Marketable yield: Sum of size classes A1 to A3.

${ }^{2}$ Size classes: $C=0.5$ to 1.5 inches, $B=1.5$ to 1.86 inches, $A 1=1.86$ to 2.5 inches, $A 2=2.5$ to 3.25 inches, $A 3=3.25$ to 4 inches, $A 4>4$ inches;

Size distribution by class: Class (wt)/(Total Yield [wt] - culls [wt]) 
Table 3. Vine maturity, tuber characteristics, and internal tuber defects of 'Fabula' potato variety grown at the UF/IFAS Hastings Agricultural Extension Center, Hastings, FL from 2001 to 2016, excluding 2009.

\begin{tabular}{|c|c|c|c|c|c|c|c|c|c|c|c|}
\hline \multirow[t]{2}{*}{ Year } & \multirow{2}{*}{$\begin{array}{c}\text { Vine } \\
\text { Maturity }\end{array}$} & \multicolumn{6}{|c|}{ Tuber Characteristics ${ }^{1}$} & \multicolumn{4}{|c|}{ Internal Tuber Defects² } \\
\hline & & $\begin{array}{c}\text { Internal } \\
\text { Flesh } \\
\text { Color }\end{array}$ & $\begin{array}{l}\text { Skin } \\
\text { Color }\end{array}$ & $\begin{array}{l}\text { Skin } \\
\text { Texture }\end{array}$ & $\begin{array}{l}\text { Tuber } \\
\text { Shape }\end{array}$ & $\begin{array}{c}\text { Eye } \\
\text { Depth }\end{array}$ & $\begin{array}{c}\text { Overall } \\
\text { Appearance }\end{array}$ & HH & BR & CRS & IHN \\
\hline 2001 & 4 & 2 & 8 & 7 & 3 & 5 & 4 & 0 & 0 & 0 & 0 \\
\hline 2002 & 4 & 3 & 7 & 7 & 4 & 7 & 5 & 0 & 0 & 0 & 0 \\
\hline 2003 & 6 & 3 & 7 & 7 & 4 & 7 & 7 & 0 & 0 & 0 & 0 \\
\hline 2004 & 7 & 3 & 7 & 8 & 5 & 8 & 8 & 0 & 0 & 0 & 0 \\
\hline 2005 & 8 & 3 & 7 & 6 & 5 & 7 & 6 & 0 & 0 & 0 & 0 \\
\hline 2006 & 9 & 2 & 7 & 6 & 4 & 6 & 6 & 0 & 0 & 0 & 0 \\
\hline 2007 & 9 & 4 & 7 & 6 & 3 & 7 & 6 & 0 & 0 & 0 & 0 \\
\hline 2008 & 7 & 2 & 7 & 6 & 3 & 7 & 6 & 0 & 0 & 0 & 0 \\
\hline 2010 & 8 & 3 & 8 & 7 & 4 & 5 & 6 & 0 & 0 & 0 & 0 \\
\hline 2011 & 8 & 3 & 7 & 7 & 4 & 3 & 6 & 0 & 0 & 0 & 0 \\
\hline 2012 & 9 & 2 & 7 & 7 & 3 & 4 & 5 & 0 & 0 & 0 & 0 \\
\hline 2013 & 8 & 3 & 7 & 6 & 4 & 3 & 5 & 0 & 0 & 3 & 0 \\
\hline 2014 & 3 & 2 & 9 & 7 & 3 & 5 & 7 & 0 & 0 & 3 & 0 \\
\hline 2015 & 5 & 2 & 9 & 8 & 3 & 7 & 7 & 0 & 0 & 0 & 0 \\
\hline 2016 & 6 & 3 & 9 & 8 & 4 & 6 & 7 & 0 & 0 & 0 & 0 \\
\hline Average & 7 & 3 & 7 & 7 & 4 & 6 & 6 & 0 & 0 & 0 & 0 \\
\hline
\end{tabular}

